\title{
Statistical Study of Impact of Mobile on Student's Life
}

\author{
Sadaf Nawaz ${ }^{1}$, Zahoor Ahmad $^{2}$ \\ ${ }_{1,2}$ (Department of Statistics, University of Gujrat, Pakistan)
}

\begin{abstract}
The adoption of the mobile phone by young people has been a global phenomenon in recent years. It is now an integral part of youngsters' daily lives and is for the majority, the most popular form of electronic communication. In fact, the mobile phone has turned from a technological tool to a social tool. This paper explores the impact of the mobile phone on youth peer relationships, on family relationships and on the institution.Young people use the mobile phone in positive ways to organize and maintain their social networks. However, there are also negative impacts on young peoples' peer relationships. These can include ostracism and cyber bullying.Demographic toolsare usedto gain insights intohow students value various mobile phone applications and tools.For this purpose a survey has been conducted. We visited five well known colleges of Gujrat city, Fatima Jinnah College, Marghazar College for Women, Government Commerce College for Boys, Gujrat College of Commerce for Girls and Gujrat College of Commerce for Boys and important data has been collected. The data have been analyzed and the results have been discussed.
\end{abstract}

\section{Introduction}

The whole world is accepting and adopting the ways towards the advancement of technology. The youth is playing a vital role in this rapid pace. The mobile phone had been in existence for about a decade before young people really adopted this technology. The reduction in the cost of the handsets, their smaller size and the introduction of the pre-paid phone card in the 1990's contributed to the surprisingly rapid adoption rate by young people(see [1] and [2]). Surveys have consistently shown that young people even prefer their mobile phone to television or the Internet (see [3] and [4]).

The mobile phone is a status symbol for young people. The features of the phone, the appearance and personalised accessories all attest to the phone's status, with sixty percent of young people reporting they were keen to upgrade their mobile phone [5]. It is seen as a fashion accessory that satisfies the need for individualisation by having choices in mobile wallpaper, ring tones, phone covers, carry bags and other accessories and yet also signifies being part of the peer group [6] [7]. Indeed, even the ownership of a mobile phone indicates that one is socially connected, accessible and in demand. It can also be seen as a symbol of independence from one's family.

\subsection{The impact of the mobile phone on the peer group:}

The impact of the mobile phone on young people's peer groups has been extensive. Adolescence is a time of change and increasing influence of the peer group [8] and thus communication amongst peer group members is central to the identity of the individual. The impact of the mobile phone on peer relationships has transformed the peer group into a truly networked society [7]

\subsubsection{Functional:}

One of the main stated reasons for young people's use of the mobile phone is functionality or 'microcoordination" of their social life. Adolescence is a time of exceeding the family boundaries and generating more extensive networks with peers. As all social life is based on ongoing interpersonal interaction, the fixed telephone has been an essential instrument to enable young people to organise their social life (see [9]).In study [10] conclude that this ability to communicate has been extended further by the use of the mobile phone which not only enables coordination free from the constraints of physical proximity, but also of spatial immobility; that is, the need to stay at specific places. The ability of the mobile phone to directly contact a person allows young people even more flexibility and spontaneity in their lives. Young people are able to arrange or rearrange social functions extremely quickly which leads to a "more fluid culture of information social interaction". 
1.1.2 Relational:

However, the most important impact the mobile phone has had, is to connect young people and their peer group. Even the functional use of the mobile phone is intertwined with the relational use; that is, it serves to link peers more closely to one another even more than the fixed phone, as it is done without adult interference. In a New Zealand study $56 \%$ of high school students reported that the most important reason for using a mobile phone was to talk and text with friends (see [5]).

1.2Impact of the mobile phone on the family

\subsubsection{Safety:}

One of the most cited reasons that parents want their children to have a mobile phone is for safety (see [6], [8] and [10]. In an Australian study, 68\% of parents reported that as their child had a mobile phone, they knew where they were at any time. There was one parent however, who acknowledged that this was only a perception. There needs to be trust in the parental child relationship, in that the child will be truthful in reporting their location. This study also found that $77 \%$ of parents reported at least one occasion when they needed to urgently contact their child but were unable to do so. Conversely $37 \%$ of young people reported that they were unable to contact their parents urgently mainly because they were out of credit (see [12]).

\subsubsection{Family Rules and negative impact:}

However, along with these positive impacts, there are negative aspects to young people's mobile phone use.Unfortunately the countries like Pakistan, India and Bangladesh have strong cultural values, rules and customs that are easily fettered by the western cultural onslaught. Our youth is concentrating on some bad choices. The telecommunication companies in our country have been inclined towards introducing new and attractive packages for youth like Mobilink (ladies first, happy hours), Warid (zem series), Ufone (public demand, prepay life panch ka pandra, u circle) Telenor (talkshawk Aone, djuice) and Zong's life package.

All necessary and normal interactions can be dealt with during daytime but the companies offer the packages that start after end of family or business communication. My feeling is that these packages are more likely to spoil and destroy our youth than to do anything else.In our youth segment the majority is student community that is spell bounded by these packages. They are losing the essence of their studies. They are getting away from their goals, destinies and motives.By talking whole night with opposite sex, they are getting psychologically weak and pressured. There are many other physical distortions also arising due to spending the precious time which is needed compulsory rest, relaxation, relief and mental health.

They are going far and far away from the hold of families. They tell lies and have false communication with their parents. They are betraying the decisions, trust and expectations of their parents.

It is interesting to note that there are few common family rules about young people's use of the mobile phone. In fact, many young people (58\%) reported that there were no rules set by their parents about their mobile phone use, and only $12 \%$ reported that their parents used removal of their mobile phones as punishment ([12]). In [5]study concluded that $26 \%$ of young mobile people reporting being threatened, with the phone being confiscated, as a form of punishment in New Zealand.

It has been found that some young people's sleep is disturbed when friends call them on their mobile phone to talk or when a text message is deposited [16]. There have also been anecdotal reports of young people texting under bedcovers at night and using their mobile phones as their alarm clock and torch. Probably because of the sleeping issue it has been found that the most common rule set by parents $(56 \%)$ was that children have to leave their mobile phones out of their rooms at night. Ten percent of young people also reported that their parents frequently had to ask them to stop using their mobile phone late at night with $12 \%$ saying that this was the most common disagreement between them and their parents [12].

\subsubsection{Financial issues:}

In addition, there are issues of financial disputes in families over mobile phone payments. In the New Zealand study $13 \%$ of those surveyed reported they had "pinched" money to spend on their phone bill [5]. Forty-one percent of the students had 'no idea' how much they spend on their phone bills per month and 34\%, reported that their parents didn't know either. 
Statistical Study of Impact of Mobile on student's life

Therefore, within the family, the adoption of the mobile phone has meant changes in power and control in the parent-child relationship because of increased freedoms as well as more micro-coordination of daily life. Thus, overall there seems to be little negative impact of the mobile phone on family relationships.

\section{Methodology}

We selected sample of $10 \%$ of the population using stratified random sampling. The data was collected using questionnaire. For stratified random sampling with proportional allocation, the sample sizes, $\mathrm{n}_{1}=152$ from Fatima Jinnah College for Girls, $\mathrm{n}_{2}=79$ fromGovernment College of Commerce (Boys), $\mathrm{n}_{3}=135$ from Marghzar College for Girls, $\mathrm{n}_{4}=90$ from Gujrat College of Commerce (Girls), $\mathrm{n}_{5}=44$ from Gujrat College of Commerce (Boys). Total respondents were 500. The data is analyzes using descriptive statistics, correlation and Hypothesis testing.

\section{RESULT AND DISCUSSION}

The minimum amount of mobile expenditure in Fatima Jinnah College is $50 \mathrm{Rs}$ and maximum is 2000. In Marghazar College the minimum amount is 100 Rs and maximum is 5000 Rs. In Gujrat college of commerce (girls) the minimum amount is $100 \mathrm{Rs}$ and maximum is 8000 Rs. Gujrat college of commerce (boys) has minimum amount 5 Rs and maximum 4000 Rs. In government college of commerce the minimum amount is 100 Rs and maximum is 5000 Rs.

Mobile price also varies from college to college. We get lowest mobile price and highest mobile price.The students have 1000 to 50000costs of mobilesin Fatima Jinnah college. The cost range is 1000 to 70000 in Marghazar College, 1500 to 45000in Gujrat College of commerce (girls) and 1000 to 22000in Gujrat College of commerce (boys), 1000 to 90000in Government College of commerce (Boys).

There are different categories of father's profession.

TABLE-1: Father Profession

\begin{tabular}{|l|l|l|l|l|l|l|l|l|l|l|}
\hline $\begin{array}{l}\text { Professi } \\
\text { on }\end{array}$ & $\begin{array}{l}\text { Businessma } \\
\mathrm{n}\end{array}$ & $\begin{array}{l}\text { Foreigne } \\
\mathrm{r}\end{array}$ & $\begin{array}{l}\text { Labou } \\
\mathrm{r}\end{array}$ & $\begin{array}{l}\text { Farme } \\
\mathrm{r}\end{array}$ & $\begin{array}{l}\text { Teache } \\
\mathrm{r}\end{array}$ & $\begin{array}{l}\text { Governmen } \\
\text { t Servant }\end{array}$ & $\begin{array}{l}\text { Builde } \\
\mathrm{r}\end{array}$ & $\begin{array}{l}\text { Lawyer } \\
\mathrm{s}\end{array}$ & $\begin{array}{l}\text { Docto } \\
\mathrm{r}\end{array}$ & $\begin{array}{l}\text { Oth } \\
\text { ers }\end{array}$ \\
\hline $\begin{array}{l}\text { Percenta } \\
\text { ge }\end{array}$ & $35 \%$ & $20.28 \%$ & $4.64 \%$ & $4.84 \%$ & $5.44 \%$ & $7.06 \%$ & $2.62 \%$ & $1.01 \%$ & $2.62 \%$ & 6.4 \\
$9 \%$
\end{tabular}

From table-1 we conclude that we conclude that in Gujrat city most people are businessman, Foreigners are at second number, many of people are government servants and others have their respective professions.

TABLE-2: Correlation Matrix

\begin{tabular}{|c|c|c|c|c|}
\hline & $\begin{array}{l}\text { Monthly Pocket } \\
\text { Money }\end{array}$ & $\begin{array}{l}\text { Monthly } \\
\text { Expenditure } \\
\text { on Mobile } \\
\end{array}$ & $\begin{array}{l}\text { Study time } \\
\text { after college } \\
\text { in a day }\end{array}$ & $\begin{array}{l}\text { Time Given to } \\
\text { mobile in a day in } \\
\text { Minutes }\end{array}$ \\
\hline $\begin{array}{l}\text { Monthly PocketMoney } \\
\text { Pearson correlation } \\
\text { Sig.(2- tailed) }\end{array}$ & 1 & $\begin{array}{l}.196^{* *} \\
.000\end{array}$ & $\begin{array}{l}-0.40 \\
.378\end{array}$ & $\begin{array}{l}0.34 \\
0.448\end{array}$ \\
\hline $\begin{array}{l}\text { Monthly Expenditure on Mobile } \\
\text { Pearson correlation } \\
\text { Sig.(2- tailed) }\end{array}$ & $\begin{array}{l}.196 \\
.000\end{array}$ & 1 & $\begin{array}{l}-0.49 \\
.280\end{array}$ & $\begin{array}{l}.140^{* *} \\
.002\end{array}$ \\
\hline $\begin{array}{l}\text { Study time after college in a day } \\
\text { Pearson correlation } \\
\text { Sig.(2- tailed) }\end{array}$ & $\begin{array}{l}-0.40 \\
.378 \\
\end{array}$ & $\begin{array}{l}-0.49 \\
.280\end{array}$ & 1 & $\begin{array}{l}-0.18 \\
.693\end{array}$ \\
\hline $\begin{array}{l}\text { Time Given to mobile in a day } \\
\text { in Minutes } \\
\text { Pearson correlation } \\
\text { Sig.(2- tailed) }\end{array}$ & $\begin{array}{l}0.34 \\
0.448\end{array}$ & $\begin{array}{l}.140^{* *} \\
.002\end{array}$ & $\begin{array}{l}-0.18 \\
.693\end{array}$ & 1 \\
\hline
\end{tabular}

** Correlation is Significant at 0.01 level (2-tailed)

From Table-2 we conclude that if pocket money of student increases the expenditure on mobile also increases. Time Given to mobile in a day and time given to study after college timing are inversely related 
Statistical Study of Impact of Mobile on student's life

with each other. It means that if student gives less time to study after college time, he gives more time to mobile. We also conclude that if he/she spends more money on mobile than he/she gives less time to study.

TABLE-3: Average

\begin{tabular}{|l|l|l|l|l|l|l|l|l|}
\hline & $\begin{array}{l}\text { Month } \\
\text { ly } \\
\text { Pocket } \\
\text { Money }\end{array}$ & $\begin{array}{l}\text { Monthly } \\
\text { Expendit } \\
\text { ure on } \\
\text { Mobile }\end{array}$ & $\begin{array}{l}\text { Dial } \\
\text { ed } \\
\text { call } \\
\text { s in } \\
\text { a } \\
\text { wee } \\
\mathrm{k}\end{array}$ & $\begin{array}{l}\text { Receive } \\
\text { d calls } \\
\text { in a } \\
\text { week }\end{array}$ & $\begin{array}{l}\text { Study } \\
\text { time } \\
\text { after } \\
\text { college } \\
\text { in a } \\
\text { day in } \\
\text { Minute } \\
\text { s }\end{array}$ & $\begin{array}{l}\text { No. } \\
\text { of } \\
\text { SMS } \\
\text { mak } \\
\text { e in } \\
\text { a } \\
\text { Day }\end{array}$ & $\begin{array}{l}\text { No. of } \\
\text { SMS } \\
\text { Recei } \\
\text { ved in } \\
\text { a Day }\end{array}$ & $\begin{array}{l}\text { Time Given } \\
\text { to mobile in } \\
\text { a day in } \\
\text { Minutes }\end{array}$ \\
\hline $\begin{array}{l}\text { Fatima Jinnah } \\
\text { College for Girls }\end{array}$ & 711 & 435 & 9 & 13 & 262 & 16 & 15 & 93 \\
\hline $\begin{array}{l}\text { Gujrat College of } \\
\text { Commerce(Boys) }\end{array}$ & 1733 & 804 & 34 & 37 & 173 & 37 & 35 & 181 \\
\hline $\begin{array}{l}\text { Gujrat College of } \\
\text { Commerce(Girls) }\end{array}$ & 1040 & 743 & 17 & 20 & 235 & 31 & 38 & 172 \\
\hline $\begin{array}{l}\text { Marghzar College } \\
\text { for Girls }\end{array}$ & 891 & 730 & 10 & 11 & 253 & 12 & 17 & 101 \\
\hline $\begin{array}{l}\text { Government College } \\
\text { of commerce(Boy) }\end{array}$ & 2430 & 625 & 34 & 39 & 177 & 40 & 45 & 215 \\
\hline Over All Mean & 1179 & 632 & 17 & 20 & 234 & 23 & 26 & 137 \\
\hline
\end{tabular}

From Table-3 we conclude that on the average student's pocket money is 1179 rupees. They spending 632 rupees on mobile. They give 137 minutes to mobile daily on the average. They give 234 minutes to study their books after college timing.

From figure 1 we can say that that $28 \%$ students use Mobilink connection, $23 \%$ use Ufone connection, $23 \%$ use Telenor connection, $17 \%$ use Warid connection, $7 \%$ use paktel connection and only $2 \%$ students use Insta connection. So there is a wide use of Mobilink connection and less use of insta connection.From fig- 2 we see that $16 \%$ use their mobile to set Alarm, $15 \%$ play Games on their mobile, $13 \%$ play songs, $12 \%$ use camera, $11 \%$ use calculator, $11 \%$ use calendar and $8 \%$ use radio function. So there is a wide use of Alarm clock function and less use of radio function among students. From fig -3 we can say that $44 \%$ students use mobile phone for dialing their family members, $37 \%$ for friends, $12 \%$ for education and $7 \%$ dial calls for other social matters.

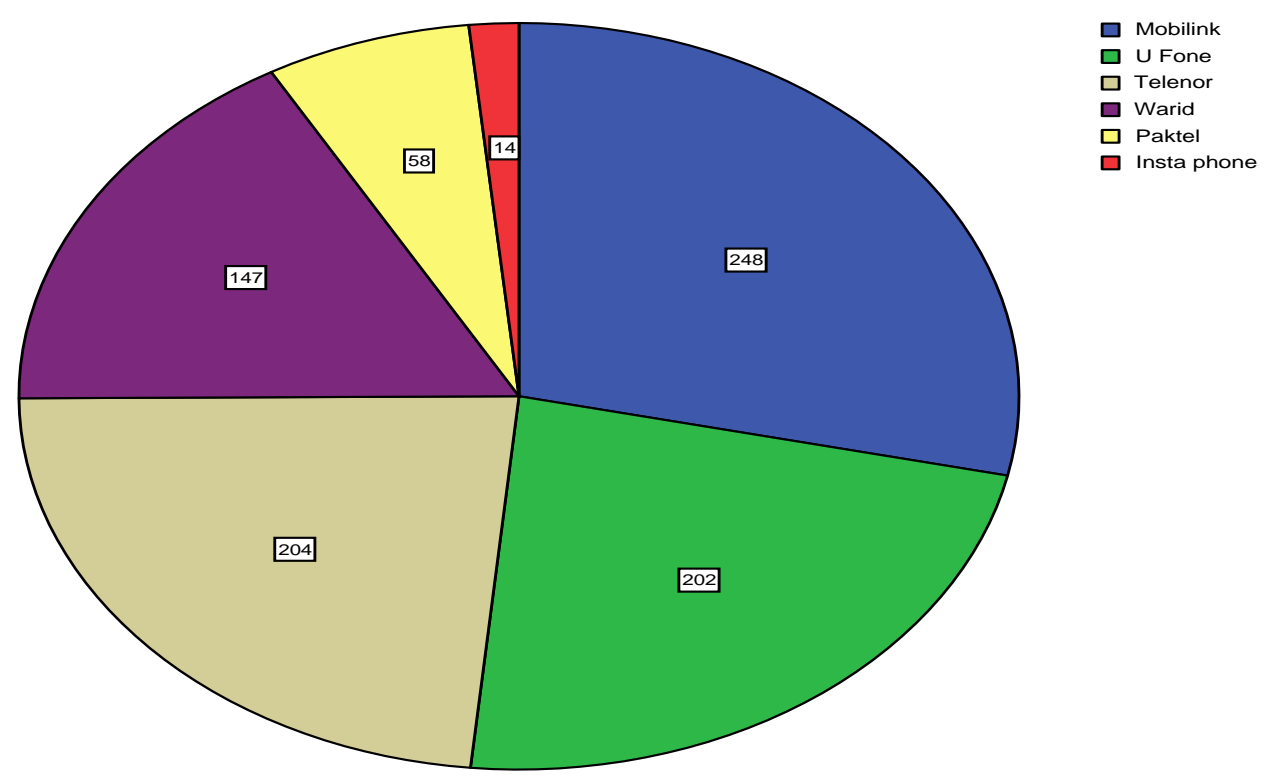

FIGHURE-1: Use of Mobile Connection 


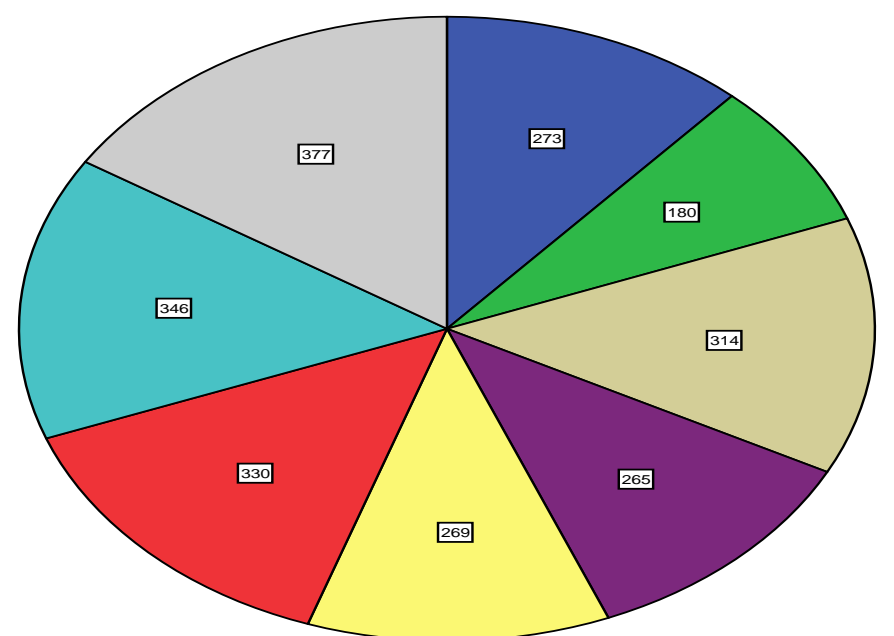

$\square$ Use For Camera

Use For Radio

U Use For Calculator

Use For Calender

Use For Time

Use For Game

Use For Game

FIGHURE-2: Use of Other functions of Mobile

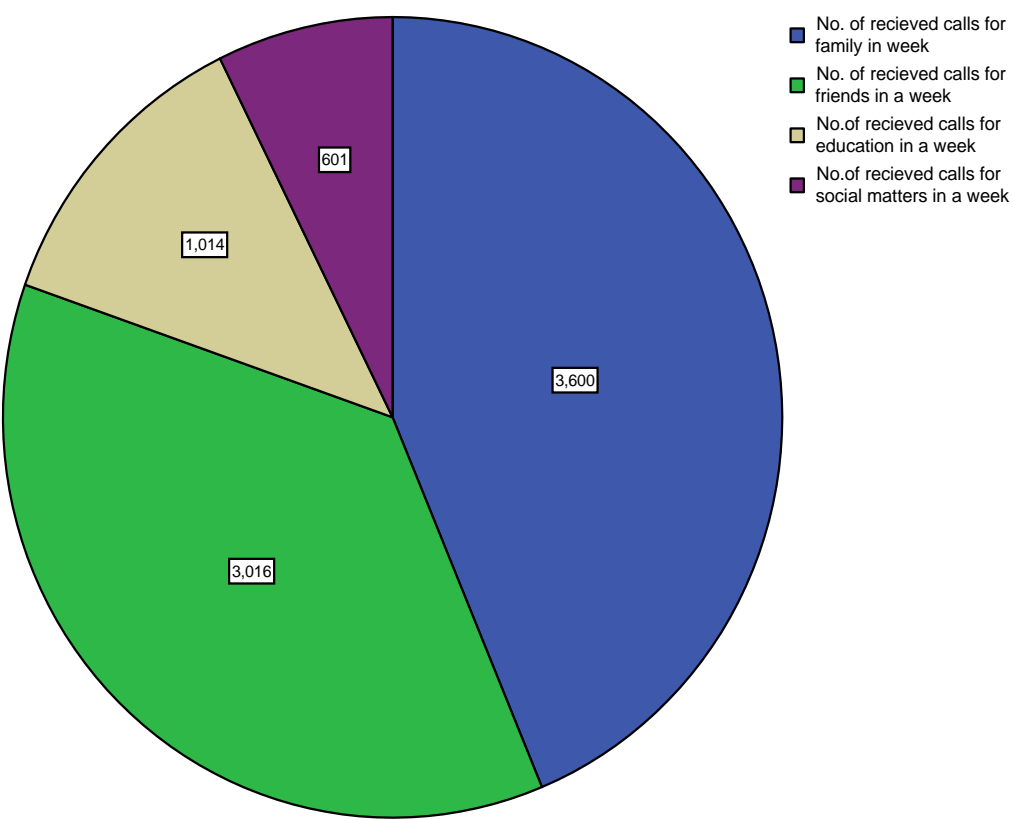

FIGHURE-3: Calls for different purposes

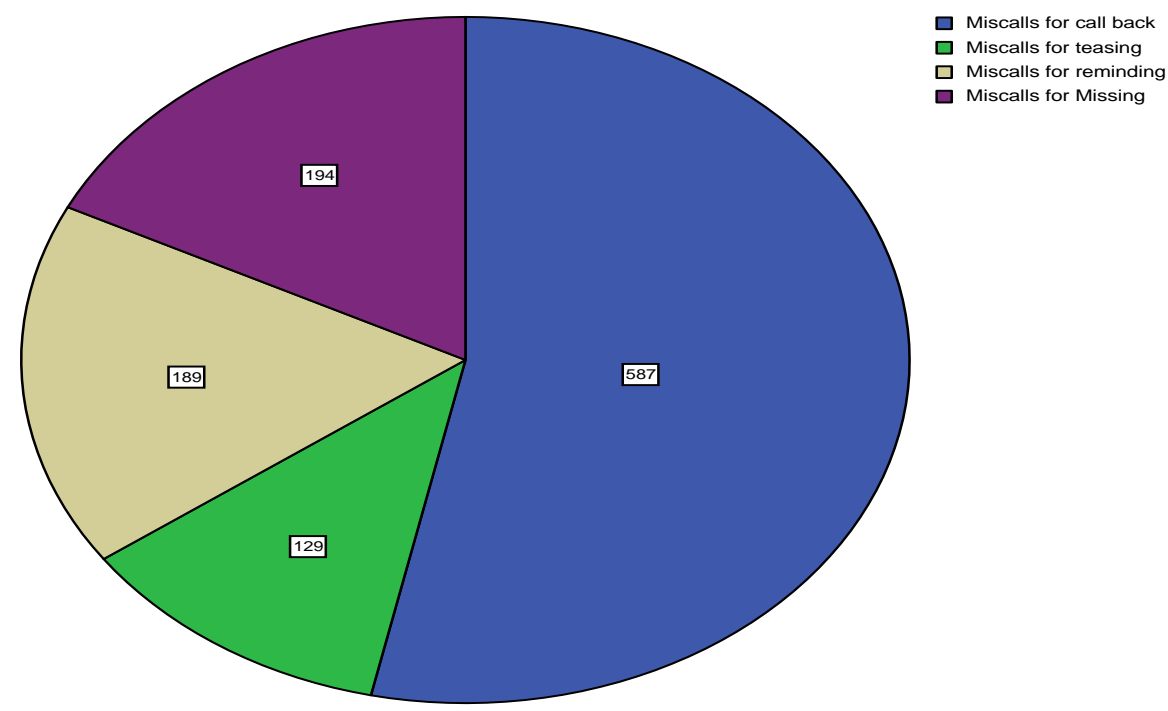

FIGHURE-4: Types of Miscalls 
From Fig-4 we can say that 53\% students make miss calls for call back, $18 \%$ make for missing, $17 \%$ make for reminding and $12 \%$ students make miss calls for teasing others.

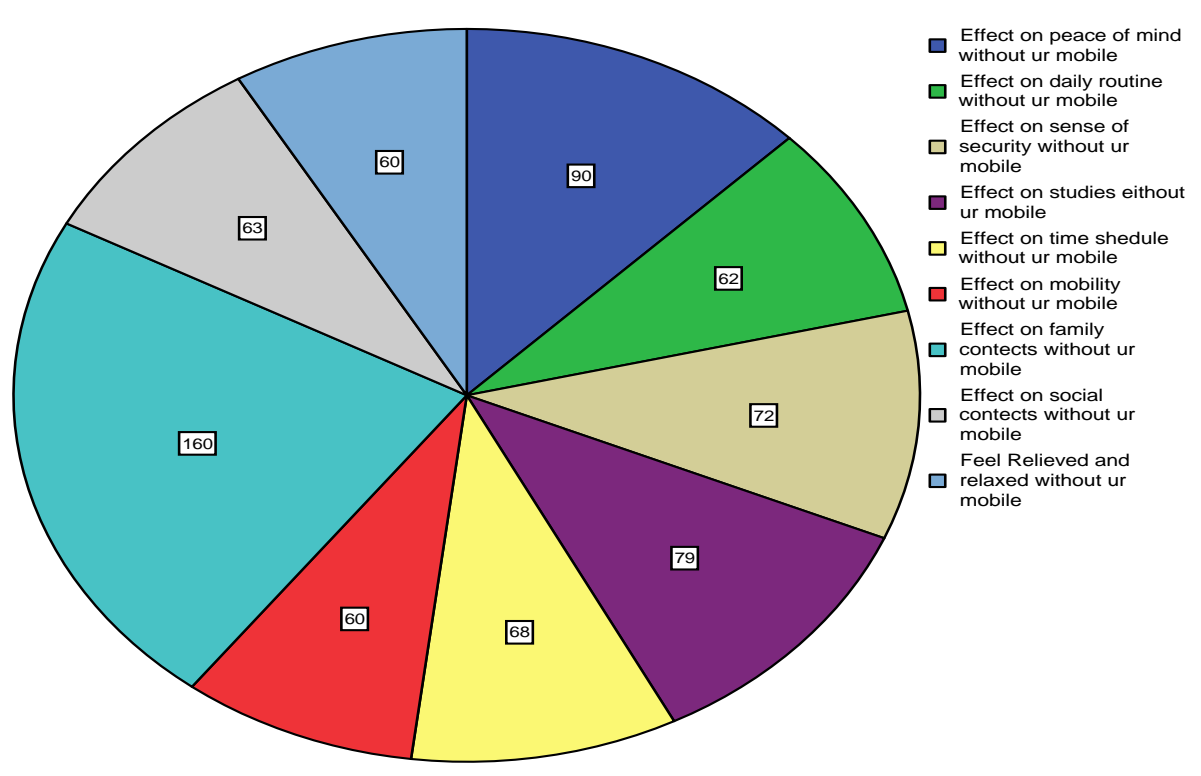

FIGHURE-5: Effect of absence of mobile

From fig- 5 we conclude that $22 \%$ students miss family contacts, $13 \%$ effect their peace of mind, $11 \%$ effect b $10 \%$ feel unsecure, $10 \%$ effect time schedule, $9 \%$ effect social contacts, $9 \%$ effect daily routine, $8 \%$ have effect on mobility and $8 \%$ students feel relieved and relaxed without mobile.

Hypothesis testing:

We assume in null hypothesis that students give 180 and less than 180 minutes to their mobile on the average against alternative hypothesis the students give greater than 180 minutes to their mobile on the average at $5 \%$ level of significance. After applying testing procedure we draw a conclusion that students give less and equal to 180 minutes time to their mobile in each college of Gujrat.

Here we claim that there is difference between average time given to mobile in a day and study for students at 5\% level of significance. After applying testing procedure we draw a conclusion on the average students give time to their mobile and study equally in Government Commerce College for Boys Gujrat College of Commerce for Boys. But on the average students do not give time to their mobile and study equally in Marghazar College, Gujrat College of Commerce for Girls College and Fatima Jinnah College.

Here we assume in null hypothesis that proportion of using night packages among the students is greater or equal to $50 \%$ at $5 \%$ level of significance. After applying testing procedure we draw a conclusion that students use night packages grater and equal to $50 \%$ in Government Commerce College for Boys and Gujrat College of Commerce for Boys. But students use night packages less than 50\% in Marghazar College, Gujrat College of Commerce for Girls College and Fatima Jinnah College.

\section{CONCULSION}

In this fast moving world mobile phones and usage is an unavoidable part of life Each and every day the technology is updating. Now we have the world is in our finger tips. Here we like to focus more on the scope, by this we can know about the students approach towards the mobile and how much it influence their life and also helps to identify what type of function which they are really interested. The usage will vary from one person to another so it's clearly being identified by using this type of studies. This help the companies to implement the customer needs and the same time they can know about to what extend the customers are satisfied with their products and services. The usage of mobile phone among the students have been increased to a great extent. Mobile phones are not considered as a device for communication alone but it is considered as a media for entertainment. This paper helps to know more about the purpose which the students are using mobile phones apart from communication. We come to know that now a day's most of the students prefer alarm in their 
mobiles. We conclude that mostly students give miss call to others for call back purpose. Frequently they dial family numbers. Generally they use Mobilink Connection. They miss their family when mobile is not present with them. They give 180 or less than 180 minutes to mobile on the average. Girls do not give equal time to mobile and study, but boys students give equal time to mobile and study. Boys mostly use night packages as compared to girls students.

\section{References}

[1] Ling, R, Adolescent girls and young adult men: Two sub-cultures of the mobile telephone. Kjelier, Telenor Research \& Development (report $\mathrm{r}$ 34/2001)

[2] Ling, R, Fashion and vulgarity in the adoption of the mobile telephone among teens in Norway. In L. Fortunati, J. E. Katz and R. Riccini (Eds.). Mediating the human body: Technology, communication and fashion, 2003, 93-102). Mahway, NJ: Lawrence Erlbaum.

[3] Enpocket (2005). Mobile media monitor survey. Retrieved 30 June, 2005, from http://www.cellular-news.com/story/13286.php

[4] Hession, E. (2001). Booty call: How marketers can cross into wireless space. Dublin: Puca. Ison, A., Hayes, A., Robinson, S., \& Jamieson, J. (2004, November). Txt Me: Supporting disengaged youth using mobile technologies. Australian Flexible Learning Framework. Retrieved August 15, 2005, from http://www.flexiblelearning.net.au

[5] Netsafe, The text generation: Mobile phones and New Zealand youth: A report of result from the internet Safety Group's survey of teenage mobile phone use. 92005 , January).

[6] Srivastava, L, Mobile phones and the evolution of social behaviour. Behaviour and Information Technology, 24, 2005, 111-129.

[7] Williams, S., \& Williams, L. (2005). Space invaders: The negotiation of teenage boundaries through the mobile phone. The Sociological Review, 53, 314-331.

[8] Ling, R., \& Helmersen, P, “It must be necessary, it has to cover a need": The adoption of mobile telephony among pre-adolescents and adolescents. Paper presented at the Social Consequences of Mobile Telephony, Oslo, Norway. (2000, June)

[9] Manceron, V, Get connected! The French Journal of Communication, 5(2), 1997, 229-241.

[10] Geser, H. (2004). Towards a sociological theory of the mobile phone. Retrieved July 12, 2005, from http://socio.ch/mobile/t_geser1.pdf

[11] Weston, P., Atkinson, S., \& Giles, D. Family terror as Internet lures gatecrashers to wrong house: 500 teens rampage. Sunday Mail, (2005, February 27). p. B13.

[12] Matthews, R., The psychosocial aspects of mobile phone use amongst adolescents. InPsych, 26(6), 2004, 16-19.

[13] Ling, R., The impact of the mobile telephone on four established social institutions. Paper presented at the International Society for the Study of European ideas conference, Bergen, Norway. (2000a, August)

[14] Davie, R., Panting, C., \& Charlton, T., Mobile phone ownership and usage among pre-adolescents. Telematics and Informatics, 21, (2004), 359-373.

[15] Roos, J. P., Sociology of cellular telephone: The Nordic model. Telecommunications, 17, 1993, 446-456.

[16] Anderson, L., Sleepless teens spend half the night calling friends. The Advertiser, 2003, p. B.7. 